\title{
EFEK HIPOGLIKEMIK EKSTRAK ETANOL UMBI KETELA RAMBAT (Ipomoea batatas P) (EEUKR) PADA MENCIT SWISS YANG DIINDUKSI ALOKSAN
}

\section{HYPOGLICEMIA EFFECT OF SWEET POTATOS (Ipomoea batatas P) ROOT ETHANOLIC EXTRACT IN ALLOXAN INDUCED SWISS MICE}

\author{
Akrom $^{1}$, Harjanti, P.D. ${ }^{2}$, Armansyah, T. ${ }^{3}$ \\ ${ }^{1}$ Fakultas Farmasi Universitas Ahmad Dahlan \\ Jl. Prof. Dr. Soepomo SH, Yogyakarta, Telp. (0274) 379418 \\ ${ }^{2}$ Fakultas Kedokteran Hewan Universitas Unsiyah \\ Email: akmaa_uad@yahoo.co.id
}

\begin{abstract}
ABSTRAK
Umbi ketela rambat banyak mengandung beta karoten, polifenol dan flavonoid. Aloksan terbukti merusak sel pankreas melalui mekanisme stress oksidatif. Senyawa betakaroten, polifenol dan flavonoid umbi ketela rambat diduga bersifat antioksidatif dan sitoprotektif sehingga menghambat kerusakan sel akibat paparan aloksan. Penelitian ini bertujuan untuk mengetahui pengaruh pemberian (Ipomoea batatas P) (EEUKR) terhadap kadar glukosa darah dan gambaran histopatologi pankreas pada mencit Swiss diinduksi aloksan. Digunakan 15 hewan uji mencit Swiss dengan rata-rata berat badan 20-30 gram. Hewan uji dibagi menjadi 5 kelompok, dimana masing-masing kelompok terdiri dari 3 ekor mencit. Kelompok I (kontrol negatif), diberi akuades. Kelompok II, III, IV dan V adalah kelompok perlakuan yang diberi EEUKR dengan dosis 2,5, 7,5, 22,5 dan 67,5 mg/KgBB/hari peroral selama 10 hari, 7 hari sebelum diinduksi dan 3 hari setelah diinduksi aloksan. Induksi aloksan dilakukan pada hari ke-7 secara intraperitoneal dengan dosis $120 \mathrm{mg} / \mathrm{Kg}$ BB. Dilakukan pemeriksaan kadar glukosa darah pada hari ke-4 dan hari ke-10 perlakuan. Pada hari ke-10 hewan uji dikorbankan. Pankreas diisolasi dan dilakukan pemeriksaan histopatologis. Dilakukan analisis varian untuk mengetahui kemaknaan perbedaan rata-rata kadar glukosa darah sewaktu antar kelompok dengan uji anova dan dilanjutkan dengan uji LSD pada taraf kepercayaan 95\%. Data histopatologi pankreas dianalisis secara kualitatif. Hasil penelitian menunjukkan bahwa EEUKR dosis 22,5 dan 67,5 $\mathrm{mg} / \mathrm{KgBB} /$ hari yang mempunyai efek sebagai agen hipoglikemia pada mencit Swiss. Kadar glukosa darah mencit Swiss sebelum diinduksi aloksan pada kelompok perlakuan dengan dosis 67,5 mg/kgBB EEUKR lebih rendah dari pada kadar glukosa darah kelompok aqua dan bermakna secara statistik $(\mathrm{p}<0,05)$. Kadar glukosa darah mencit Swiss yang telah diinduksi aloksan pada kelompok perlakuan dosis 22,5 dan 67,5 mg/kgBB EEUKR lebih rendah dari pada kadar glukosa darah kelompok normal dan bermakna secara statistik $(\mathrm{p}<0.05)$. Secara histopatologis persentase gambaran nekrosis pankreas mencit Swiss yang diinduksi aloksan pada kelompok perlakuan dosis 22,5 dan 67,5 mg/kgBB lebih rendah dari pada persentase nekrosis kelompok akua. Berdasarkan hasil penelitian tersebut maka dapat disimpulkan bahwa EEUKR dosis 22,5 dan $67,5 \mathrm{mg} / \mathrm{KgBB}$ terbukti bersifat hipoglikemik pada mencit Swiss baik sebelum maupun setelah diinduksi aloksan. EEUKR juga terbukti menurunkan kejadian nekrosis pada pankreas mencit Swiss yang diinduksi aloksan.
\end{abstract}

Kata kunci: ekstrak etanol umbi ketela rambat (EEUKR), efek hipoglikemik, induksi aloksan, diabetes mellitus. 


\begin{abstract}
Sweet potatos rood contain lots of beta-carotene, polyphenols and flavonoids. Alloxan proven pancreatic cell damage through oxidative stress mechanisms. The compound beta-carotene, polyphenols and flavonoids are thought to antioxidative and cytoprotective, inhibit cell damage caused by alloxan exposure. This study aimed to determine the effect of ethanolic extract of sweet potatos (Ipomoea batatas P) (EEUKR) on blood glucose levels and pancreatic histopathology on alloxaninduced Swiss mice. Used 15 test animals, Swiss mice, with an average weight of 20-30 grams. Test animals were divided into 5 groups, with each group consisting of 3 mice. Group I was the negative control group who were given distilled water (akua group), and group II, III, IV and V are the treatment group were given ethanolic extract of sweet potatos rood (EEUKR) at a dose of 2.5, 7.5, 22.5 and $67.5 \mathrm{mg} / \mathrm{KgBW} /$ day orally for 10 days, 7 days before and 3 days after the alloxan induced. Alloxan induction performed on the 7th day intraperitoneally at a dose of $120 \mathrm{mg} / \mathrm{kgBW}$. Examination of blood glucose levels conducted on 4 th and day $10^{\text {th }}$ day of treatment. On the 10th day of the test animals were sacrificed for isolated pancreas and histopathologic examination. Analysis of variance conducted to determine the significance difference in average blood glucose levels between groups during the test and ANOVA followed by LSD test at 95\% confidence level. Pancreatic histopathology data were analyzed qualitatively. The results showed that the EEUKR dose of 22.5 and 67.5 $\mathrm{mg} / \mathrm{kgBW} /$ day had the effect of hypoglycemia in Swiss mice. Blood glucose levels of Swiss mice before alloxan induced in treatment group with EEUKR dose of $67,5 \mathrm{mg} / \mathrm{Kg}$ BW were lower than blood glucose levels of akua groups, statistically significant ( $<<0,05)$. Blood glucose levels of alloxan induced swiss mice of treatment groups with EEUKR dose of 22.5 and $67.5 \mathrm{mg} / \mathrm{KgBW}$ were lower than blood glucose level of akua group and statistically significant $(p<0.05)$. The percentage of pancreatic necrosis of alloxan-induced Swiss mice of treatment groups with EEUKR dose of 22.5 and $67.5 \mathrm{mg} / \mathrm{kg} \mathrm{BW}$ were lower than the percentage of necrosis of akua group. Based on these results it can be concluded that the EEUKR doses of 22.5 and $67.5 \mathrm{mg} / \mathrm{KgBW}$ are found to be hypoglycemic in Swiss mice both before and after alloxan induced. The EEUR also shown to decrease the incidence of pancreatic necrosis in alloxan-induced Swiss mice.
\end{abstract}

Keywords: ethanol extract of sweet potatos rood (EEUKR), hypoglycemic effect, induction of alloxan, diabetes mellitus

\section{PENDAHULUAN}

Ketela rambat (Ipomoea batatas, P.) merupakan salah satu sumber vitamin A alamiah yang murah dan mudah didapatkan di Indonesia. Ketela rambat merupakan salah satu tanaman yang memiliki kandungan beta karoten, polifenol dan serat tinggi (Padda, 2006; Hue et al., 2012). Pada tiap $100 \mathrm{mg}$ ketela rambat bisa mengandung beta karoten berkisar 260-9000 $\mu \mathrm{g}$ (Nur, 2004). Beta karoten merupakan provitamin A utama dengan efek antioksidan (Padda, 2006), imunomodulator (Dawiesah, 1988), meningkatkan "komunikasi" interselular, dan antikarsinogenik. Kemampuan beta karoten sebagai antioksidan ditunjukkan dengan kemampuannya mengikat oksigen radikal, radikal peroksil dan menghambat oksidasi lipid. Studi epidemiologi menunjukkan bahwa rendahnya beta karoten plasma dan konsentrasi karotenoid berhubungan dengan meningkatnya resiko kanker esophagus, lambung dan kanker kulit seperti halnya penyakit kardiovaskuler (Supriyono, 2008). Kandungan polifenol dan flavonoid (antosianin) umbi ketela rambat juga terbukti sebagai scavenger radikal bebas (Padda, 2006; Tokusoglu \&Yildirim, 2011; Hue, 2012). Sampai saat ini pemanfaatan ketela rambat masih sangat terbatas.

Diabetes Melitus (DM) adalah penyakit metabolik yang ditandai dengan hiperglikemia akibat insufisiensi jumlah dan fungsi insulin sehingga terjadi abnormalitas metabolism karbohidrat, lemak dan protein (Soegondo et al., 2011). Penyakit DM merupakan salah satu penyakit tak menular di Indonesia yang membutuhkan perhatian, karena insidensi dan 
prefalensinya semakin meningkat dan dapat berakibat fatal (Cockram, 2000; Wild et al., 2004; Li, 2009). Faktor-faktor yang berhubungan dengan peningkatan prevalensi DM di Indonesia antara lain perubahan pola makan masyarakat, peningkatan jumlah anak obesitas, urbanisasi, kebiasaan merokok dan kurang berolah raga (Wild et al., 2004; Soegondo et al., 2011). Berbagai komplikasi akut dan kronis dapat menyerang penderita DM akibat stress oksidatif yang ditimbulkan oleh kondisi hiperglikemi (Arnita, 2005). Konsumsi umbi ketela rambat yang kaya beta karoten, polifenol dan flavonoid lainnya diharapkan dapat membantu mengurangi progresifitas penyakit dan timbulnya komplikasi sebagai akibat pencegahan terjadinya stress oksidatif, namun belum banyak dilakukan penelitian tentang hal ini.

Hormon insulin mempunyai peran utama dalam mengatur kadar glukosa darah. Kekurangan kadar insulin atau tidak adekuatnya aktifitas hormon insulin oleh karena menurunnya sensitifitas reseptor insulin menyebabkan terganggunya homeostasis glukosa darah (Soegondo et al., 2011). Kadar glukosa darah normal dipelihara pada 80-120 mg \% waktu puasa dan 80-160 mg \% dua jam sesudah makan (Edem, 2009). Paparan senyawa diabetogenik aloksan menurunkan kadar insulin dan mengganggu homeostasis glukosa darah (Zhang et al., 2002; Li et al., 2009). Aloksan merupakan senyawa diabetogenik yang bersifat sitotoksik terhadap sel islet pankreas melalui pembentukan radikal bebas dan stress oksidatif (Nugroho, 2006). Induksi aloksan pada hewan uji merusak jaringan pankreas sehingga terjadi penurunan produksi insulin oleh sel islet pankreas (Szkuldeski, 2001; Nugroho, 2006). Tiga puluh menit setelah induksi aloksan, organ limpa mengalami stress oksidatif dan terjadi aktivas $\mathrm{NFKb}$ pada sel islet pankreas sehingga memacu reaksi radang (Zhang et al., 2002). Penelitian terhadap mekanisme kerja aloksan secara in vitro menunjukkan bahwa aloksan menginduksi pengeluaran ion kalsium dari mitokondria yang mengakibatkan proses oksidasi sel terganggu. Keluarnya ion kalsium dari mitokondria ini mengakibatkan gangguan homeiostatis yang merupakan awal dari matinya sel (Suharmiati, 2003).
Ketela rambat mengandung beta karoten dengan kadar yang tinggi (Nur, 2004; Becker \& Van De Brink, 1965). Ekstraksi dengan etanol dapat mensarikan beta karotene pada umbi ketela rambat. Kadar beta karoten yang tinggi diharapkan dapat berlaku sebagai antioksidan dan dapat mencegah kerusakan sel islet pankreas akibat induksi aloksan. Berdasarkan latar belakang tersebut maka tujuan penelitian ini adalah mengetahui pengaruh pemberian EEUKR terhadap kadar glukosa darah dan gambaran histopatologi pankreas pada mencit jantan galur Swiss yang diinduksi aloksan.

\section{METODE PENELITIAN}

\section{Alat}

Inkubator $\mathrm{CO} 2$, sentrifuse, microplate reader, inverted microscope, Tabung reaksi, spuit injeksi, laminar air flow hood, mikro pipet dan alat-alat gelas serta objek gelas.

\section{Bahan}

Umbi ketela rambat dari pasar tradisional dipilih yang berwarna orange; Etanol 96\% untuk proses ekstraksi umbi ketela rambat diperoleh dari distributor Sigma. Hewan uji mencit Swiss jantan diperoleh dari Unit Pengembangan Hewan Percobaan (UPHP) UGM. Seperangkat alat bedah untuk isolasi organ pankreas; formalin dan pewarna HE untuk pembuatan sediaan histopatologi organ pankreas.

\section{Jalannya Penelitian}

\section{Identifikasi, ekstraksi dan pembuatan sediaan}

Umbi ketela rambat (I. batatas P.) diidentifikasikan dengan metode morfologi mikroskopis (Jackson \& Snowdan, 1968). Sebagian bahan uji dibuat sediaan mikroskopis dan diamati secara mikroskop dengan perbesaran 10x10. Identifikasi umbi dilakukan dengan mencocokkan gambaran mikroskopis susunan umbi yang diuji dengan susunan umbi ketela rambat sebagaimana yang terdapat pada buku "Powdered Vegetable Drugs: An Atlas of Mikroscopy for use in The Identification and Authentication of Some Plant Materials Employed as Medicinal Agents" (Jackson \& 
Snowdan, 1968). Identifikasi umbi ketela rambat dilakukan oleh tenaga Ahli di Laboratorium Biologi Farmasi Fakultas Farmasi UGM.

Pembuatan serbuk umbi ketela rambat dilakukan sesuai dengan panduan (Anonim, 1986). Umbi ketela rambat yang masih segar dicuci dengan air mengalir sampai bersih, kemudian ditiriskan, dikupas kulitnya dan dirajang dengan menggunakan pisau kemudian dikeringkan. Pengeringan dilakukan dengan menggunakan lemari pengering pada suhu $50^{\circ} \mathrm{C}$, setelah kering dihaluskan dengan blender dan diperoleh serbuk umbi ketela rambat yang kemudian ditimbang diperoleh beratnya 450 gram.

Pembuatan EEUKR dilakukan sesuai pembuatan ekstrak yang baik sebagaimana ditetapkan oleh Depkes (Anonim, 1992). Sediaan EEUKR dibuat dengan metode maserasi, menggunakan modifikasi metode yang digunakan oleh Li et al. (2009) dengan metode yang terdapat pada buku pedoman pembuatan sediaan galenik (Anonim, 1986). Secara ringkas prosedur ekstraksi sebagai berikut: bahan sebanyak $450 \mathrm{~g}$ yang telah diserbuk ditambahkan $1250 \mathrm{~mL}$ etanol $96 \% \mathrm{v} / \mathrm{v}$ sampai semua bahan terendam dan diaduk dengan pengaduk elektrik, kemudian didiamkan selama 1 malam sambil ditutup rapat. Setelah disimpan selama semalam filtrat dipisahkan dengan penyaringan yang dilakukan menggunakan corong Buchner dengan pengurangan tekanan. Filtrat kemudian disimpan dalam lemari es sebagai filtrat I, selanjutnya ampas disari lagi dengan etanol 96\% perlakuan sama dengan filtrat I, hingga diperoleh filtrat II dan III. Etanol yang ditambahkan berturut-turut $1000 \mathrm{~mL}$ dan $750 \mathrm{~mL}$. ketiga filtrat tersebut dikumpulkan dan dituang dalam cawan porselin yang sebelumnya telah ditimbang dan untuk menghilangkan cairan penyarinya, filtrat tersebut diuapkan di atas penangas air dengan pemanasan rendah. Proses ini dilakukan hingga bobot ekstrak kental konstan dan tidak memberikan bau etanol. Setelah bobot ekstrak stabil kemudian ekstrak ditimbang (Anonim, 1986; Anonim 1992; Li et al., 2009).

\section{Uji antidiabetes sediaan EEUKR}

Tikus diadaptasikan terlebih dahulu sebelum diberi perlakuan. Mencit Swiss dengan berat badan kurang lebih 20 gr sebanyak 15 ekor dibagi menjadi 5 kelompok tiap kelompok masing-masing terdiri dari 3 ekor. Selama 10 hari semua kelompok diberi perlakuan yang berbeda tetapi berada pada lingkungan dan mendapatkan makan dan minum yang sama.

Sediaan EEUKR diberikan secara peroral dengan volume maksimal 0,5 mL (Edem, 2009). Kelompok pertama sebagai kelompok aloksan, hewan uji hanya mendapatkan akuades peroral selama 10 hari dan induksi aloksan pada hari ke7 perlakuan. Kelompok kedua, ketiga, keempat dan kelima sebagai kelompok perlakuan, masingmasing diberi EEUKR dengan dosis 2,5mg/kgBB/hari, $\quad 7,5 \mathrm{mg} / \mathrm{kg} / \mathrm{BB} / \mathrm{hari}, \quad 22,5$ $\mathrm{mg} / \mathrm{kgBB} / \mathrm{hari}$ dan $67,5 \mathrm{mg} / \mathrm{kgBB} /$ hari selama 10 hari dan pada hari ke-7 diinduksi aloksan. Sebelum diinduksi aloksan, pada hari ke-4 dilakukan pengambilan darah untuk pengukuran kadar glukosa darah sebelum diinduksi aloksan. Setelah diinduksi aloksan pada hari ke-7 pemberian EEUKR pada kelompok perlakuan dilanjutkan sampai ke-10. Pada hari ke- 10 setelah dilakukan pengambilan darah untuk pengukuran kadar gula darah kemudian semua hewan uji dikorbankan untuk diisolasi organ pankreas untuk pemeriksaan histopatologi ( $\mathrm{Li}$ et al., 2009).

Diabetogen aloksan diberikan pada hari ke-7 perlakuan secara injeksi intraperitoneal dengan dosis tunggal $120 \mathrm{mg} / \mathrm{Kg} \mathrm{BB}$ dengan prosedur sesuai dengan yang dilakukan oleh peneliti sebelumnya (Li et al., 2009). Larutan stok aloksan dibuat dengan kadar $5 \% \mathrm{~b} / \mathrm{v}$. Prosedur singkat pembuatan larutan aloksan adalah sebagai berikut: ditimbang serbuk aloksan monohidrat sebanyak 0,5 gr kemudian dilarutkan dengan akuades hingga volume 10 $\mathrm{mL}$. Volume pemberian larutan aloksan: 0,5 mL/tikus (Li et al., 2009).

Pada hari ke-10 perlakuan (3 hari setelah injeksi aloksan) kadar glukosa darah diperiksa dengan mengambil darah dari vena orbitalis. Penetapan kadar glukosa darah dengan metode Enzymatic Photometric Test (spektofometer) sebagaimana dilakukan oleh peneliti sebelumnya (Georgewill \& Georgewill, 2009). Darah diambil sebanyak $1 \mathrm{ml}$ dari sinus orbitalis ditampung dalam tabung sentrifuga mikro kemudian disentrifugasi selama lima belas menit pada 
putaran $4000 \mathrm{rpm}$. Serum akan terpisah dari komponen darah dan berada di bagian atas. Serum berupa supernatan yang jernih diambil dengan memakai pipet berskala yang sesuai dengan jumlah volume yang diperlukan. Serum darah dipindahkan ke dalam tabung-tabung kecil diberi pereaksi dan divortek agar homogen, untuk menentukan kadar glukosa darah dilakukan dengan alat spektrofotometer pada panjang gelombang tertentu (panjang gelombang maksimal) (Georgewill \& Georgewill, 2009).

Dengan pipet mikro, dimasukkan ke dalam tabung reaksi sebagai berikut:

\begin{tabular}{ccc}
\hline & Blangko & $\begin{array}{c}\text { Larutan } \\
\text { sampel/standar }\end{array}$ \\
\hline $\begin{array}{c}\text { Larutan } \\
\text { sampel/standar } \\
\text { Reagen }\end{array}$ & $1000 \mu \mathrm{l}$ & $10 \mu \mathrm{l}$ \\
\hline
\end{tabular}

Masing-masing dicampur, diinkubasi selama 20 menit pada suhu $20-25^{\circ} \mathrm{C}$ atau 10 menit pada suhu $37^{\circ} \mathrm{C}$. Serapan dibaca dalam 60 menit diameter dalam kuvet $1 \mathrm{~cm}$. Kadar glukosa darah dihitung dengan rumus:

Kadar glukosa darah $(\mathrm{A})=\frac{A s}{A s t} \times 100 \mathrm{mg} / \mathrm{dl}$.

\section{Keterangan}

$\mathrm{A} \quad=$ Serapan pada panjang gelombang maksimum.

As = Serapan larutan uji.

Ast = Serapan larutan baku (larutan glukosa standar).

\section{Pemeriksaan histopatologi}

Pemeriksaan histopatologi dilakukan setelah pemberian perlakuan selama 10 hari. Tujuan pemeriksaan histopatologi adalah untuk mengetahui kemungkinan adanya perubahan struktur jaringan pancreas hewan uji yang disebabkan adanya pemberian EEUKR dan aloksan. Prosedur ringkas pemeriksaan histopatologi adalah sebagai berikut (Eliakimikechukwu et al., 2009).

\section{a. Pengambilan organ}

Pengambilan organ dilakukan 24 jam setelah pemberian larutan uji atau setelah waktu perpanjangan, yang dilakukan sebagai berikut: mencit dikorbankan kemudian dipotong kulit perutnya hingga terlihat isi dari perut. Organ pankreas yang ingin diperiksa diangkat, kemudian dibersihkan dengan larutan $\mathrm{NaCl}$ 0,9\% dan dimasukkan ke dalam pot berisi formalin $10 \%$.

b. Pembuatan preparat histopatologi dan pemeriksaan jaringan

Pembuatan preparat histopatologi dilakukan di Laboratorium Patologi Fakultas Kedokteran Hewan Universitas Gadjah Mada Yogyakarta dengan pengecatan hematoksilin dan eosin (HE).

Pemeriksaan dan pemotretan jaringan dilakukan di Laboratorium Patologi Kedokteran Hewan Universitas Gadjah. Pembacaan sediaan histopatologi pankreas terhadap adanya gambaran kerusakan sel, gambaran vakuola atau adanya reaksi inflamasi akibat induksi aloksan dilakukan oleh Ahli patologi.

\section{Analisis data}

Hasil pemeriksaan kadar gula darah dilakukan uji perbedaan rata-rata. Uji kemaknaan perbedaan rata-rata antar kelompok pada satu waktu pengujian dan antar waktu pengujian dilakukan untuk menilai adanya pengaruh pemberian EEUKR pada hewan uji.

Uji One Sample Kolmogorof-Smirnov dilakukan untuk mengetahui semua varian/kelompok terdistribusi normal atau tidak. Menggunakan uji Levene, jika data tidak homogen dilanjutkan dengan menggunakan metode statistik non parametrik (Uji KruskalWallis dan Uji Mann-Whitney). Jika diperoleh data memilki varian yang homogen dilanjutkan dengan menggunakan metode parametrik yaitu uji Anova dilanjutkan dengan uji LSD.

Hasil pemeriksaan sediaan histopatologi pankreas dianalisis secara kualitatif oleh Ahli disajikan secara diskriptif dengan parameter pengamatan: (i). gambaran reaksi inflamasi dan (ii) tanda-tanda kerusakan sel dengan adanya vakuola dalam sel. Hasil analisis dilaporkan sebagai persentase kenormalan. 


\section{HASIL DAN PEMBAHASAN}

\section{Hasil Identifikasi Umbi dan Ekstraksi}

Pada penelitian ini bagian tanaman ketela rambat yang digunakan adalah umbinya. Umbi ketela rambat yang dipakai adalah jenis yang berwarna orang kemerahan. Berdasarkan hasil identifikasi umbi secara mikroskopik dengan buku Powdered Vegetable Drugs "An Atlas of Microscopy for use in the Identification and Authentication of some Plant Materials Employed as Medicinal Agents" (Jackson dan Snowdon, 1968) dipastikan umbi yang duji adalah umbi ketela rambat. Hasil identifikasi secara mikroskopik dapat dilihat pada Gambar 1.

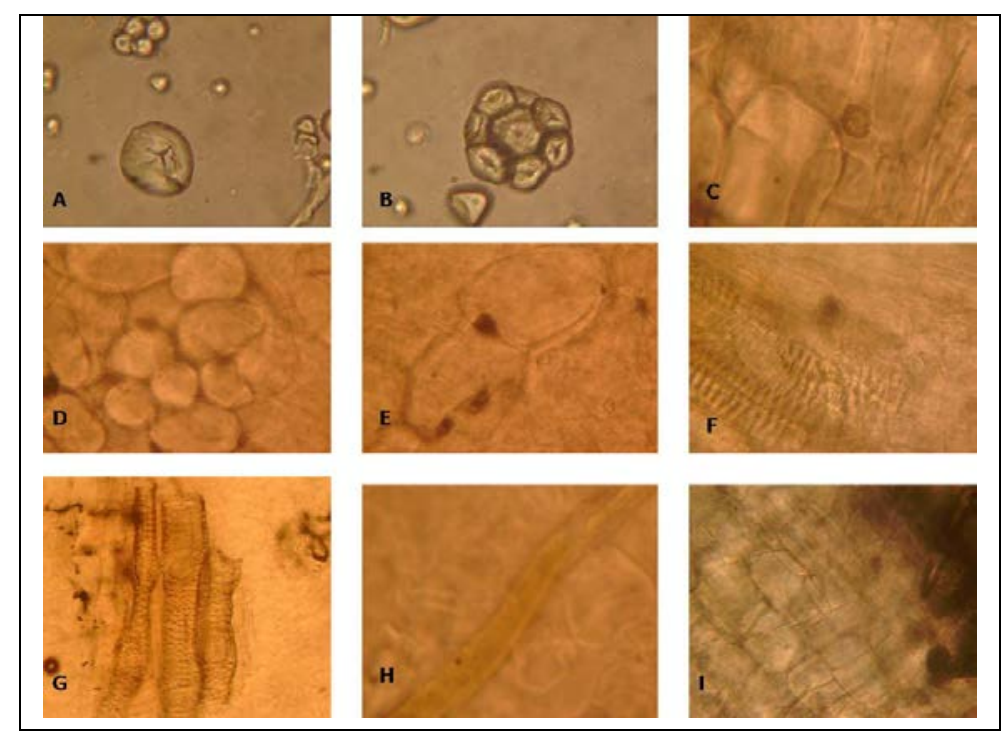

Gambar 1. Identifikasi serbuk umbi ketela rambat secara mikroskopik. Keterangan : A. Amilum hilus sentries, B. Amilum majemuk, C. Parenkim silinder pusat, D. Parenkim kortek, E. Parenkim dan kristal Ca Oksalat bentuk truzen, F. Parenkim dan berkas pengangkut dengan penebalan bentuk tangga, G. Unsur-unsur berkas pengangkut trakea, $H$. Serabut sklerenkim, i. Sel gabus.

Dari serbuk umbi ketela rambat seberat 450 gram diperoleh ekstrak etanol umbi ketela rambat 40,65 g. Rendeman ekstrak etanol umbi ketela rambat yang diperoleh secara maserasi adalah 9,03 \%. Uji organoleptik diperoleh hasil seperti pasta berwarna jingga kecoklatan dengan rasa yang sedikit pahit dan bau yang khas. Ekstraksi dengan metode maserasi dengan pelarut etanol $96 \%$ diharapkan mampu mengambil senyawa betakaroten, polifenol dan flavonoid dari umbi ketela rambat dan zat aktif tidak mengalami kerusakan sebagaimana dilakukan peneliti sebelumnya (Tokusoglo et al., 2012).

\section{Hasil Uji anti diabetes sediaan EEUKR}

Hasil pemeriksaan kadar glukosa darah pada hari ketiga sebelum dan tiga hari setelah diinduksi aloksan disajikan dalam Tabel I.
Dari Tabel I terlihat bahwa pemberian EEUKR memiliki efek menurunkan kadar glukosa darah hewan uji. Rata-rata kadar glukosa darah pada kelompok perlakuan lebih rendah dari rata-rata kadar glukosa kelompok normal (akua), kecuali kelompok perlakuan dengan pemberian EEUKR dosis 2,5 mg/KgBB/hari.

Kelompok perlakuan dengan dosis 67,5 mg/KgBB EEUKR memiliki rata-rata kadar glukosa darah paling rendah dan berbeda bermakna dengan kelompok normal $(\mathrm{p}<0.05)$. Rata-rata kadar glukosa darah kelompok perlakuan dengan pemberian EEUKR dosis 7,5 dan 22,5 mg/KgBB lebih rendah dari rata-rata kadar glukosa kelompok normal tetapi perbedaan rata-rata tersebut tidak bermakna $(\mathrm{p}>0.05)$. Dari hasil pemeriksaan kadar glukosa darah hari 
ketiga setelah diinduksi aloksan terlihat bahwa rata-rata kadar glukosa darah hewan uji setelah induksi lebih tinggi dari pada sebelum diinduksi $(\mathrm{p}<0.05)$.
Induksi aloksan terbukti meningkatkan kadar glukosa darah hewan uji. Gambaran perbedaan kadar glukosa darah mencit Swiss sebelum dan setelah pemberian aloksan disajikan pada Gambar 2.

Tabel I. Kadar glukosa darah (mg/dl) masing-masing kelompok perlakuan pada tiga hari sebelum dan tiga hari setelah di induksi aloksan.

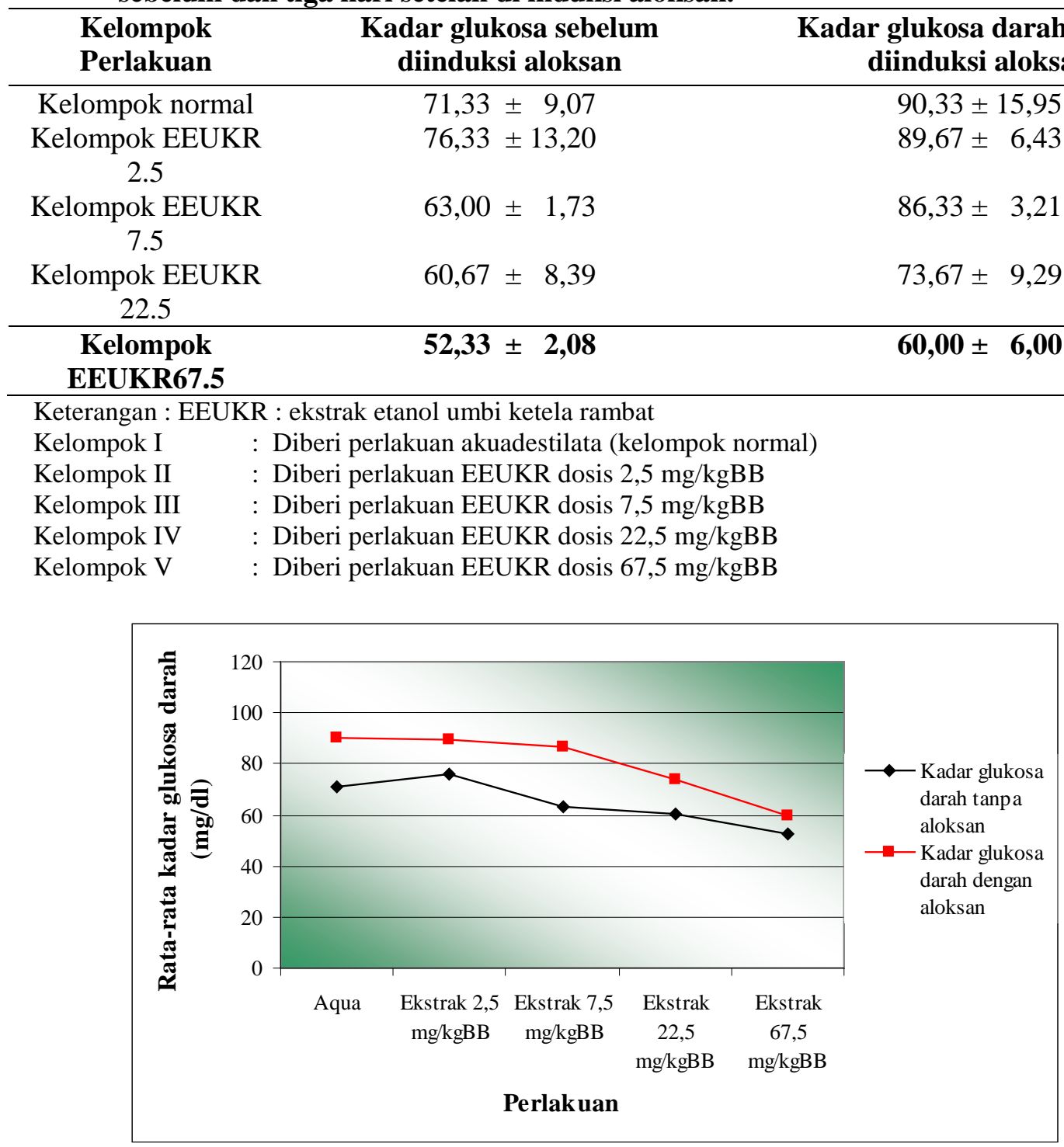

\section{Gambar 2. Grafik hubungan antara perlakuan dengan rata-rata kadar glukosa darah pada} hari ketiga sebelum dan sesudah diinduksi aloksan

Dari Gambar 2 tampak bahwa kadar glukosa darah hewan uji kelompok akua paling tinggi dari pada kadar glukosa darah kelompok lainnya. Kelompok perlakuan yang mendapatkan EEUKR 22,5 dan 67,5 mg/Kg BB memiliki ratarata kadar glukosa lebih rendah dari kelompok akua $(\mathrm{p}<0.05)$ baik sebelum maupun setelah induksi aloksan. Rata-rata kadar glukosa kelompok perlakuan yang mendapatkan EEUKR 2,5 dan 7,5 mg/KgBB tidak berbeda dengan kadar glukosa kelompok normal ( $>00,05)$. Hasil penelitian menunjukkan bahwa semakin besar dosis EEUKR yang diberikan maka penurunan kadar glukosa darah semakin besar. Dosis EEUKR yang menimbulkan penurunan kadar glukosa darah paling banyak adalah dosis 67.5 
mg/kgBB, kemudian diikuti dosis 22,5 mg/KgBB. Berdasarkan hasil analisis data kadar glukosa darah dapat disimpulkan bahwa pemberian EEUKR mempunyai efek menurunkan kadar glukosa darah mencit Swiss baik pada pengukuran sebelum maupun setelah induksi aloksan. Pemberian EEUKR dosis 67,5 $\mathrm{mg} / \mathrm{KgBB}$ merupakan dosis yang paling efektif dalam menurunkan kadar glukosa darah pada hewan uji mencit Swiss pada sebelum maupun setelah diinduksi aloksan.

\section{Hasil Pemeriksaan Histopatologi}

Pemeriksaan histopatologi bertujuan untuk melihat adanya kerusakan organ di tingkat seluler yang tidak tampak oleh pengamatan makroskopik. Organ yang diperiksa yaitu organ pankreas mencit karena pankreas merupakan tempat dimana insulin diproduksi. Tabel II menyajikan hasil pemeriksaan histopatologi organ pankreas hewan uji setelah diinduksi aloksan.

Tabel II. Hasil pemeriksaan histopatologi organ pankreas mencit Swiss hari ketiga setelah pemberian aloksan

\begin{tabular}{lcccc}
\hline Kelompok & Tikus 1 & Tikus 2 & Tikus 3 & Persentase kenormalan \\
\hline Akua+aloksan & Ne & Ne, V & N, R & $100 \%$ \\
EEUKR2.5+aloksan & No & Ne & Ne & $33 \%$ \\
EEUKR7.5+aloksan & No & No & N & $67 \%$ \\
EEUKR22.5+ aloksan & No & Ne & No & $67 \%$ \\
EEUKR 67.5+ Aloksan & Ne & No & No & $67 \%$ \\
& & & \\
\hline
\end{tabular}

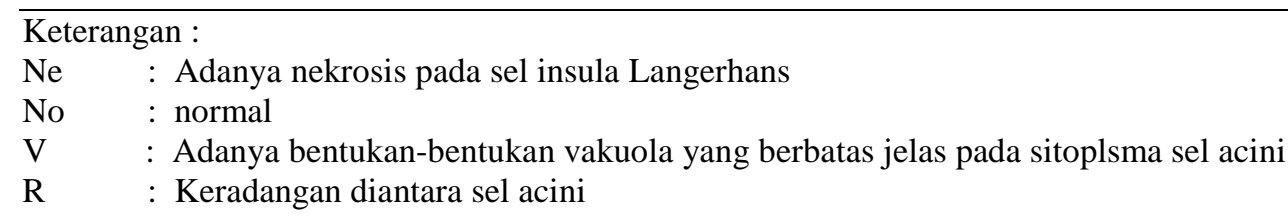

Pemeriksaan histopatologi dilakukan setelah hewan uji diberi perlakuan selama 10 hari, pada hari ketiga setelah perlakuan dan hari kesepuluh atau hari ketiga setelah diinduksi aloksan mencit dikorbankan diangkat organ pankreasnya. Hasil pemeriksaan histopatologi organ pankreas secara mikroskopis pada hewan uji setelah diberi aloksan dapat dilihat pada Gambar 3 A.

Dari Tabel II dan Gambar 3 dapat diketahui hasil pengamatan histopatologi organ pankreas mencit Swiss pada hari ketiga setelah induksi aloksan. Dari Tabel 2 diketahui bahwa kerusakan yang terjadi pada organ pankreas adalah bervariasi tergatung dosis pemberian EEUKR. Kerusakan organ pankreas yang ada yaitu nekrosis pada sel insula Langerhans, terbentuknya vakuola yang berbatas jelas pada sel acini dan peradangan diantara sel acini.

Gambar 3 menyajkan gambaran histopatologis organ pankreas yang mengalami perubahan spesifik. Hasil penelitian menunjukkan bahwa kelompok perlakuan yang mendapatkan EEUKR dosis 2,5, 7,5, 22,5 dan
$67,5 \mathrm{mg} / \mathrm{kg}$ BB tidak mengalami perubahan gambaran histopatologi yang spesifik, sebagian besar masih dalam batas normal, berbeda dengan perubahan histopatologis yang terjadi pada kelompok akua atau control negative yang tidak mendapatkan EEUKR. Kelompok akua atau control negatif yang tidak mendapatkan EEUKR setelah diinduksi aloksan mengalami perubahan yang spesifik berupa nekrosis di sekitar sel insula Langerhans, tebentuknya vakuola yang berbatas jelas pada sitoplasma sel acini dan adanya peradangan diantara sel acini. Gambaran histopatologi pancreas kelompok perlakuan yang mendapakan EEUKR meskipun adanya gambaran nekrosis tetapi tidak ada gambaran sebukan sel radang. Pemberian EEUKR pada hewan uji juga terbukti dapat menurunkan reaksi inflamasi sehingga pada kelompok perlakuan yang mendapatkan EEUKR pada sediaan histopatologis tidak menunjukkan adanya gambaran sebukan sel-sel radang sebanyak pada kelompok akua. Dari hasil pemeriksaan histopatologi ini terbukti bahwa pemberian EEUKR dengan dosis bervariasi selama 10 hari dapat menghambat kerusakan sel islet pankreas akibat induksi aloksan. 


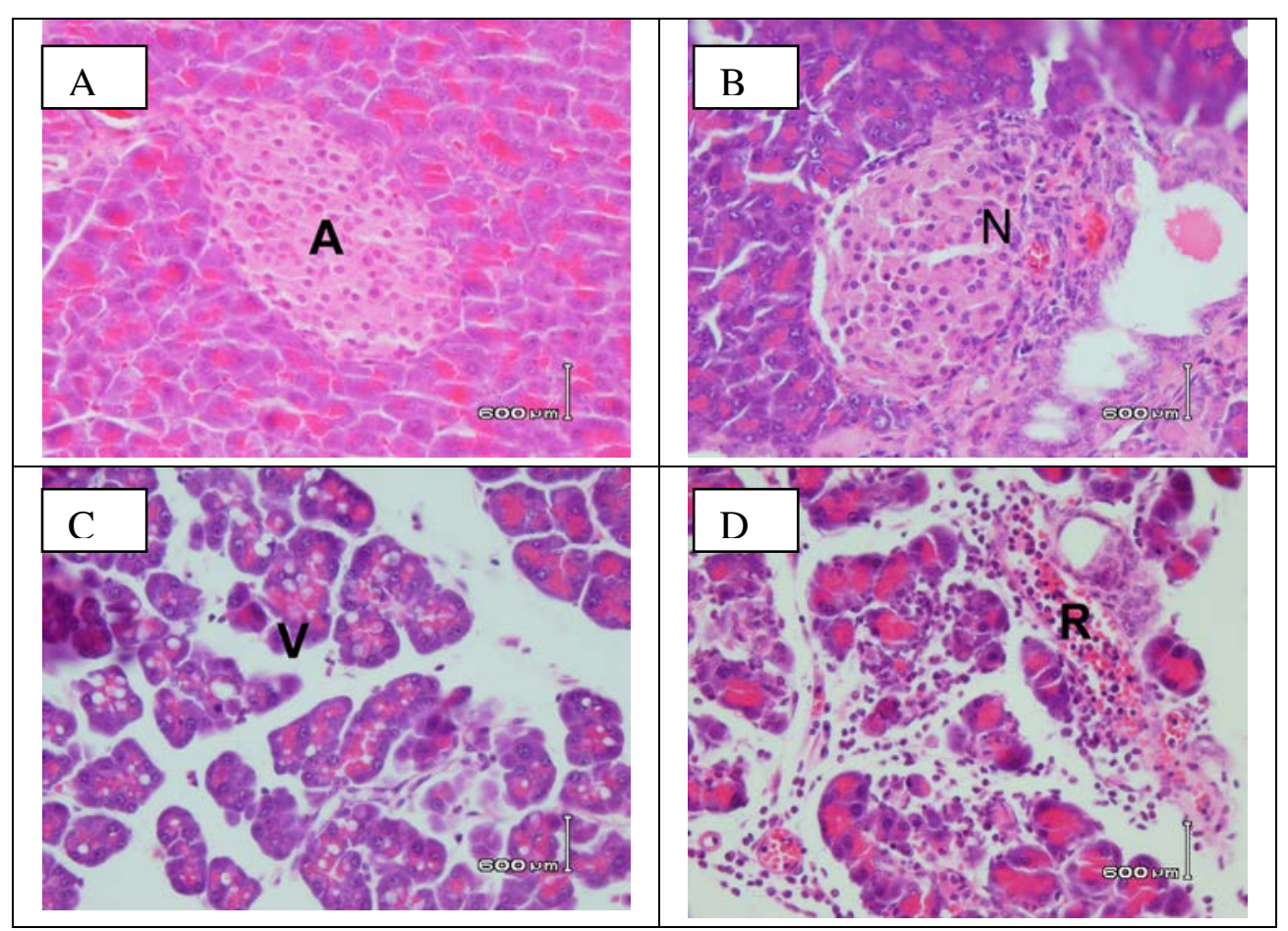

Gambar 3. A. Gambaran histopatologi organ pankreas yang tidak mengalami perubahan dengan pengecatan hematoksilin eosin (HE) perbesaran100x, A adalah pulau Langerhans. B. Gambaran histopatologi organ pankreas yang mengalami nekrosis (N) pada sel insula Langerhans dengan pengecatan hamatoksilin eosin (HE) perbesaran 400x terjadi pada kelompok perlakuan yang diberi akua + aloksan dan kelompok EEUKR dosis 2,5; 7,5; 22,5; 67,5 mg/kgBB) + aloksan. C. Gambaran histopatologi organ pankreas yang mengalami kerusakan terbentuknya vakuola (V) yang berbatas jelas pada sitoplasma sel acini dengan pengecatan hamatoksilin eosin (HE) perbesaran 100x terjadi pada kelompok perlakuan yang diberi ekstrak etanol umbi ketela rambat (dosis 2,5; 22,5 mg/kgBB)+ aloksan. D. Gambaran histopatologi organ pankreas yang mengalami radang (R) diantar sel acini dengan pengecatan hamatoksilin eosin (HE) perbesaran 100x terjadi pada kelompok perlakuan yang diberi akua + aloksan.

Hasil penelitian menunjukkan bahwa kadar glukosa darah setelah induksi aloksan lebih tinggi dari pada kadar glukosa darah sebelum induksi aloksan. Hasil pemeriksaan histopatologis organ pankreas juga membuktikan bahwa induksi aloksan hari ketujuh perlakuan dapat merusak organ pankreas dan diikuti dengan peningkatan kadar glukosa darah secara nyata. Hasil penelitian ini menunjukkan bahwa kenaikan kadar glukosa darah hewan uji setelah induksi berhubungan dengan kerusakan organ pankreas. Pada penelitian ini EEUKR dosis 67,5 dan 22,5 mg/kgBB mampu menurunkan kadar glukosa darah mencit baik pada pengukuran kadar glukosa darah sebelum maupun setelah induksi aloksan. Efek penurunan kadar glukosa darah akibat pemberian EEUKR pada mencit setelah diinduksi aloksan tampak lebih nyata, terutama pada dosis 22,5 dan 67,5 mg/Kg BB. Kadar glukosa darah kelompok EEUKR dosis 67,5 $\mathrm{mg} / \mathrm{KgBB}$ hampir setara dengan kadar glukosa darah sebelum diberi aloksan. Hasil penelitian ini menunjukkan bahwa EEUKR dapat menurunkan kadar glukosa darah baik sebelum maupun setelah pankreas mengalami kerusakan akibat induksi aloksan. Kemungkinan mekanisme kerja EEUKR dalam menurunkan kadar glukosa darah sebelum diinduksi aloksan berbeda dengan setelah induksi aloksan.

Pemberian aloksan berefek pada degradasi sel-sel $\beta$ pada pulau Langerhans, yaitu organ yang bertanggungjawab dalam pembuatan insulin di dalam tubuh. Mekanisme aksi aloksan dalam merusak sel-sel $\beta$ pulau Langerhans belum diketahui dengan jelas. Beberapa hipotesis tentang mekanisme aksi aloksan sebagai diabetogen antara lain melalui 
mekanisme pembentukan khelat terhadap Zn dan mempengaruhi terhadap enzim-enzim sel $\beta$ sehingga terjadi deaminasi dan dekarboksilasi asam amino (Nugroho, 2006). Stres genotoksik akibat pembentukan khelat ini kemudian berakibat pada kerusakan sel dan timbulnya reaksi radang. Infiltrasi sel radang (Gambar 3) menunjukkan adanya peningkatan aliran darah dalam pulau Langerhans akibat pemberian aloksan yang bekerja pada sel $\beta$ (Jerry, 1983). Pemberian EEUKR yang banyak mengandung betakaroten, polifenol dan flavonoid dapat menghambat pembentukan khelat melalui mekanisme antioksidan sehingga sel islet pankreas terlindungi dari terjadinya stress genotoksik (Hue et al., 2012)

Penelitian terhadap mekanisme kerja aloksan secara in vitro menunjukkan bahwa aloksan menginduksi pengeluaran ion kalsium dari mitokondria yang mengakibatkan proses oksidasi sel terganggu (Eliakim-ikechukwu et al., 2009). Keluarnya ion kalsium dari mitokondria ini mengakibatkan gangguan homeostasis yang merupakan awal matinya sel (Jerry et al., 1983). Dengan rusaknya sel-sel $\beta$ pulau Langerhans maka tubuh akan kehilangan insulin secara absolut sehingga sangat tergantung pada insulin dari luar tubuh (Edem, 2009). Tipe diabetes yang diperoleh dengan menggunakan aloksan tetrahidrat sebagai induktor diabetes mirip dengan diabetes tipe satu. Dalam keadaan yang agak berat, diabetes yang terjadi akan ditandai dengan adanya benda keton di dalam urin (ketoasidosis) (Georgewill \& Georgewill, 2009). Peningkatan kadar glukosa darah terjadi setelah pemberian aloksan tetrahidrat dengan dosis $120 \mathrm{mg} / \mathrm{kgBB}$.

Perubahan pada pankreas yang dapat teramati dalam penelitian ini adalah terjadi penyusutan ukuran pulau langerhans, inti sel pulau langerhans piknotik dengan sitoplasma tampak lebih eosinofilik, dan nampak adanya infiltrasi limfosit (Gambar 3). Inti sel yang mengalami piknotik menunjukkan adanya nekrosis. Bila ada pengaruh agen berbahaya pada sel (zat toksik) yang cukup berat, sel tidak dapat melangsungkan metabolisme sehingga terjadi kerusakan yang bersifat irreversible (Jerry et al., 1983; Zhang et al., 2002). Nekrosis menyebabkan perubahan- perubahan lisis yang melibatkan sitoplasma sel, yang dicirikan dengan adanya bentukanbentukan vakuola (Gambar 3), tetapi perubahan yang paling jelas pada inti sel yaitu berupa kematian sel. Biasanya inti sel yang mati terlihat menyusut batasnya tidak jelas dan berwarna gelap, proses ini dinamakan piknosis dan intinya piknotik. Menurut Edem (2009), pada diabetes jumlah pulau Langerhans berkurang, terkadang ditemukan degranulasi sel $\beta$, fibrosis dan infiltrasi limfosit. Pemberian EEUKR yang banyak mengandung betakaroten bersifat antioksidatif dan dapat melindungi kerusakan pankreas akibat paparan aloksan (Shergides et al., 2002; Maryam, 2003)

\section{KESIMPULAN}

Pemberian ekstrak etanol umbi ketela rambat dosis $67,5 \mathrm{mg} / \mathrm{kgBB}$ dapat mencegah kerusakan organ pancreas akibat paparan aloksan dan menurunkan kadar glukosa darah pada mencit swiss yang diinduksi aloksan.

\section{SARAN}

Perlu dilakukan penelitian lanjutan untuk mengetahui zat aktif dan mekanisme aksi antioksidan zat aktif tersebut dalam mencegah kerusakan pancreas pada mencit jantan galur Swiss yang diinduksi aloksan. Selain itu, perli dilakukan penelitian untuk mengetahui mekanisme hipoglikemik zat aktif EEUKR diluar mekanisme antioksidan yang mencegah kerusakan organ pancreas dan efek samping pemberian ubi jalar terhadap histopatologi organ hati pada mencit jantan galur Swiss.

\section{DAFTAR PUSTAKA}

Nur, A. 2004. Makalah Pribadi Filsafah Sains (PPS 702), Sekolah Pasca Sarjana/S3, Institut Pertanian Bogor.

Anonim. 1986. Sediaan Galenik, 4-31, 56-57, Departemen Kesehatan Republik Indonesia, Jakarta.

Anonim. 1992. Keputusan Menteri Republik Indonesia no 761/MENKES/IX/1992 tentang Pedoman fitofarmaka, 
Direktorat Jendral Pengawasan Obat dan Makanan, Departemen Kesehatan Republik Indonesia, Jakarta.

Arnita. 2005. Wahana Komunikasi Lintas Spesialis, hal 38, Farmacia, Vol IV, No II.

Backer, C. A, dan Van De Brink, R.C.B. 1965. Flora of Java Vol I, Waltersnoordhoff N. V, Groningen The Nederlands.

Cockram, C.S. 2000. The epidemiology of diabetes mellitus in the Asia-Pacific region, $H K M J$;6:43-52.

Dawiesah, I. 1988. Biokimia Vitamin A, Vitamin A, Aspek Klinis dan Komunitas, hal 1-9 Disampaikan dalam Pertemuan Ilmiah Periodik II Laboratorium IKA, Fakultas Kedokteran UGM, IDAI Yogyakarta, di Yogyakarta 18 Juni 1988.

Edem, D.O. 2009. Hypoglycemic Effects of Ethanolic Extracts of Alligator Pear Seed (Persea Americana Mill) in Rats, European Journal of Scientific Research, 33,4 ,669-678.

Eliakim-ikechukwu, C.F., Obri, A.L. 2009. Histological Changes In The Pancreas Following Administration Of Ethanolic Extract Of Alchornea Cordifolia Leaf In Alloxan- Induced Diabetic Wistar Rats., Nigerian Journal of Physiological Sciences, 24 (2): $153-155$.

Georgewill, U.O., Georgewill, O.A. 2009. Effect of extract of Pseudocedrela kotschyi on blood glucose conccentration of alloxan induced diabetic albino rats, Eastern Journal of Medicine, 1, 17-19.

Hue, S., Boyce, A.N., Somasundram, C. 2012. Antioxidant activity, phenolic and flavonoid contents in the leaves of different varieties of sweet potato (Ipomoea batatas), AJCS, 6(3):375380.
Hutapea, J. R., dan Syamsuhidayat, S.S. 1991. Inventaris Tanaman Obat, Jilid I, hal 308-309, Badan Penelitian dan Pengembangan Kesehatan, Departemen Kesehatan Republik Indonesia, Jakarta.

Jackson, B. P., and Snowdon, D. W. 1968. Powdered Vegetable Drugs “ An Atlas of Microsopy for use in the Identification and Authentication of same Plant Materials Employed as Medicinal Agents”, 104 J. \& A Churchill Ltd. Gloucester Place, London.

Jerry, R., Co1ca,.S., Kotagal, N., Brooks, C.L., Lacy, P.E., Landt, M., McDaniel, M.L. 1983. Alloxan Inhibition of a Ca2+- and Calmodulin-dependent Protein Kinase Activity in Pancreatic Islets, The Journal of Biological Chemistry,258, 12, 7260-7263.

Li, F., Li, Q., Gao, D., Peng, Y. 2009. The optimal Extraction Parameters and Antidiabetic Activity Of Flavonoids From Ipomea Batatas Leaf, Afr. $J$. Traditional, 6 (2): 195 - 202.

Maryam, S. 2003. Defisiensi dan Toksisitas Vitamin St_maryam2003@yahoo.com.

Nugroho, A.E. 2006. Hewan Percobaan Diabetes Mellitus : Patologi Dan Mekanisme Aksi Diabetogenik, Biodiversitas, 7, 4, 378-382.

Padda, M.S. 2006. Phenolic Composition And Antioxidant Activity Of Sweet Potatoes [Ipomea Batatas (L.) LAM], Dissertation, The Department of Horticulture the Graduate Faculty of the Louisiana State University and Agricultural and Mechanical College, 2006.

Serghides, L. 2002. Mechanism of Protection Induced by Vitamin A in Falciparum Malaria, Lancet, 23,4, 359-371. 
Soegondo, S., Widyahening, I.S., Istiantho, R., Yunir, M. 2011. Prevalence of Diabetes Among Suburban Population of Ternate - A Small Remote Island in The Eastern Part of Indonesia, Acta Med Indones-Indones J Intern Med., 43, 2, 99-108.

Suharmiati.. 2003. Pengujian Bioaktivitas Anti Diabetes Mellitus Tumbuhan Obat, Jurnal Cermin Dunia Kedokteran ,140, 8-12.

Szkudelski, T. 2001. The Mechanism of Alloxan and Streptozotocin Action in B Cells of the Rat Pancreas, Physiol. Res. 50: 536-546.

Tokusoglo, O., Yildirim, Z. 2012. Effect Of Cooking Methods On The
Anthocyanin Levels and Antioxidant Activity Of A Local Turkish Sweet Potatos [Ipomoea batatas (L.) LAM] Cultivar Hatay Kirmizi: Boiling, Steaming and Frying Effects, Turkish Journal of Field Crops, 17(1):87-90.

Wild, S., Roglic, G., Green, A., Sicree, R., King,H. 2004. Global Prevalence of Diabetes, Diabetes Care 27:10471053.

Zhang, H., He, J., Yuan, L., Lin, Z. 2002. In vitro and in vivo protective effect of Ganoderma lucidum polysaccharides on alloxan-induced pancreatic islets damage, Life Sciences, 73, 2307-2319. 